\title{
Grand Challenges to Support the Freshwater Biodiversity Emergency Recovery Plan
}

\author{
Angela H. Arthington* \\ Australian Rivers Institute, Griffith University, Brisbane, QLD, Australia
}

Keywords: biodiversity, ecosystem services, multiple stressors, restoration, protected areas, socio-ecological governance, stakeholders

\section{INTRODUCTION}

The year 2021 offers a critical opportunity for concerted action to influence the future of freshwater biodiversity, ecosystem services and human well-being. The United Nations Decade on Biodiversity 2011-2020 has ended, and governments around the world are reviewing major international agreements relevant to biodiversity conservation, including the Convention on Biological Diversity $(\mathrm{CBD})^{1}$, the Sustainable Development Goals (SDGs) ${ }^{2}$, and the UN Framework Convention on Climate Change (UNFCCC) ${ }^{3}$. A Post-2020 Global Biodiversity Framework ${ }^{4}$ is under development,

OPEN ACCESS

Edited by:

Martin Siegert,

Imperial College London,

United Kingdom

Reviewed by:

David Tickner,

World Wide Fund for Nature,

United Kingdom

Juergen Geist,

Technical University of

Munich, Germany

${ }^{*}$ Correspondence:

Angela H. Arthington

a.arthington@griffith.edu.au

Specialty section:

This article was submitted to

Freshwater Science,

a section of the journal

Frontiers in Environmental Science

Received: 05 February 2021

Accepted: 06 April 2021

Published: 10 May 2021

Citation:

Arthington AH (2021) Grand

Challenges to Support the Freshwater

Biodiversity Emergency Recovery

Plan. Front. Environ. Sci. 9:664313.

doi: $10.3389 /$ fenvs.2021.664313 with the grand mission to "Halt the loss of species, ecosystems and genetic diversity by 2030; restore and recover biodiversity to ensure a world of people "living in harmony with nature' by 2050 ".

Freshwater ecologists have acted quickly to draw attention to the global dimensions of the freshwater biodiversity crisis and address the lack of a comprehensive framework to guide policy responses (Bunn, 2016; Darwall et al., 2018). An Emergency Recovery Plan for freshwater biodiversity, published by 25 authors from 14 organizations (Tickner et al., 2020), sets out six major priorities for global action and policy development to "bend the curve of freshwater biodiversity loss." It has been submitted to the working committees of the Post-2020 Global Biodiversity Framework, and further promoted as a dramatic OUPblog "Bring living waters back to our

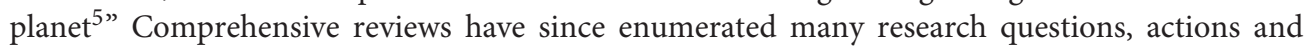
policy refinements needed to "bend the curve" and protect the world's freshwater ecosystems (van Rees et al., 2020; Buxton et al., 2021; Harper et al., 2021; Maasri et al., 2021). Each review cuts across important scientific, societal, management and policy issues.

The purpose of this brief challenge paper is, likewise, to strengthen and support the Emergency Recovery Plan, but in a different way, by advocating a broader package of strategic activities that too often operate in silos, with patchy coverage of the world's freshwater ecosystem types and biogeographic diversity. This package presents traditional areas of scientific and societal activity that require more strategic, integrated and collaborative global effort to deliver evidence-based freshwater conservation outcomes, conjoined with terrestrial and estuarine/marine conservation, depending on context: (i) inventory, evaluation and research; (ii) restoration and rehabilitation; (iii) protected area design and management; and (iv) socio-ecological science and governance. The paper is intended to motivate greater interest, commitment and collaboration of all stakeholders in the most urgent and ambitious conservation enterprise of the next decade-to protect and sustain freshwater biodiversity in the socio-ecological systems of the Anthropocene.

\footnotetext{
${ }^{1}$ https://www.cbd.int/convention/guide/?id=web4

${ }^{2}$ https://sustainabledevelopment.un.org/sdgs

${ }^{3}$ https://www.iucn.org/theme/global-policy/our-work/united-nations-framework-convention-climate-change- unfccc

${ }^{4}$ http://www.fao.org/forestry/48209-0cb7240cc9f200dcf507a40e71c39a591.pdfs

${ }^{5}$ https://blog.oup.com/2020/09/bring-living-waters-back-to-our-planet/
} 


\section{INVENTORY, EVALUATION AND RESEARCH}

Evidence-based ecosystem restoration and biodiversity protection depend upon a credible foundation of scientific and sociological data, process understanding and a capacity to model, predict and evaluate ecological/societal outcomes from natural processes, pressures and management actions. Notwithstanding a huge body of erudite freshwater research, there remains an ongoing need to increase understanding of the biodiversity, biophysical processes and ecosystem services of the world's freshwater and connected terrestrial and estuarine/marine ecosystems. The IUCN Commission on Ecosystem Management has developed a globally consistent, spatially explicit Ecosystem Typology for conservation purposes (Keith et al., 2021). It is designed to help identify the ecosystems most critical to conservation of biodiversity and supply of ecosystem services, as well as structuring global risk assessments for the Red List of Ecosystems and reporting against CBD and SDG targets and other framings. The typology distinguishes 28 natural freshwater ecosystem types within subterranean systems, palustrine wetlands, streams, rivers, freshwater and saline lakes, artesian springs, oases, and transitional waters (fjords, estuaries, intermittently closed and open lakes and lagoons-ICOLLS).

Depending on ecosystem type, geography and knowledge gaps, freshwater inventory and research is traditionally integrated around taxonomy, genetics and organismal biology, population and community ecology, and ecosystem functions, the latter including the processes that link landscapes, connected boundary systems (riparian areas, floodplains, wetlands/lakes, and groundwater systems) and freshwater ecosystems (Geist, 2011; Reis et al., 2017; Flitcroft et al., 2019). Likewise, the pathways and processes that connect rivers and estuaries via surface flows and submarine groundwater discharges are vital dimensions of interconnected freshwater and coastal ecosystems. The IUCN Ecosystem Typology provides a geographic framing and scientific resource to help guide priorities for basic inventory and ecological research on understudied ecosystem types and biogeographic regions. For example, groundwater-dependent ecosystems such as artesian springs and oases are relatively poorly studied but coming to attention globally (Cantonati et al., 2020). Intermittent rivers and ephemeral streams (IRES) and episodic arid-zone floodplains are of growing interest because even when dry they perform multiple ecosystem services that complement those of nearby perennial rivers (Datry et al., 2018). Given the exceptional biodiversity of the Amazon Basin and poor knowledge of many aquatic taxa (e.g., migratory fishes), there is an outstanding need for inventory, knowledge synthesis and risk assessment to guide recovery and conservation (Duponchelle et al., 2021).

Innovative biodiversity assessment techniques (remote sensing, GIS, environmental DNA, camera traps, sound recordings, radiotelemetry) can be integrated with established field methods to document biodiversity patterns and hotspots, and track flagship, umbrella and endangered species of high conservation value (Harper et al., 2021). Systematic reviews, meta-analysis, natural and laboratory experiments and modeling offer scope to relate biodiversity patterns and processes with dominant environmental drivers (climate, hydrological regime and water quality, etc). Broad stakeholder engagement is essential across the spectrum of biodiversity inventories, identification of knowledge gaps and research priorities, evaluation of ecosystem services and formulation of targets for restoration and protection of species, ecosystem processes and valued services.

\section{RESTORATION AND REHABILITATION}

The major threats to freshwater ecosystems have been comprehensively synthesized in six main categories: hydrological alterations, habitat degradation and loss, pollution, overexploitation, invasive species, and climate change (Dudgeon et al., 2006). These have been mapped at global scale (Vörösmarty et al., 2010; Reis et al., 2017; Grill et al., 2019), elaborated as new pollutants and configurations of stress emerge (Reid et al., 2019) and widely publicized (Bunn, 2016; Flitcroft et al., 2019). Yet despite prodigious management efforts, biodiversity loss and ecosystem degradation continue, creating huge deprivation for millions of people whose diets and livelihoods depend directly on freshwater biota (Lynch et al., 2016). Biodiversity decline has significant implications for ecosystem resilience, recovery potential and adaptation to climate change.

The Emergency Recovery Plan offers a blueprint focused on reducing biodiversity decline and recovering from these major threats, a well as a new threat category on connectivity to highlight the implications of habitat fragmentation for freshwater biota and ecosystems (Grill et al., 2019). Numerous methods and sound protocols already enable mitigation of these major threats, as demonstrated in successful ecological restoration projects around the world (Palmer et al., 2005). For example, the restoration of connectivity patterns and processes has contributed to recovery of biodiversity and ecosystem processes in many regulated rivers (Horne et al., 2017; Opperman et al., 2019). The bolder objective of the Emergency Recovery Plan is to transition from local freshwater restoration successes to a strategic approach that achieves biodiversity and ecological recovery at larger spatial scales. The European Water Framework Directive $^{6}$ offers one well-established jurisdictional framing for freshwater ecosystem recovery to good ecological status. Building on European case studies, challenges and successes under this and other directives, van Rees et al. (2020) extend the ideas of the freshwater Emergency Recovery Plan into 15 special recommendations with potential to protect freshwater life globally.

Beyond the main categories of threat to freshwater biodiversity and ecosystems lie new kinds of stress and new configurations of familiar stressors (Reid et al., 2019). Many, if not most, freshwater ecosystems are affected by several types of stress that interact, often with effects greater than (synergism), less than (antagonism) or equal to the sum of their individual effects (Sabater et al., 2018). The daunting scientific challenge is to identify the most significant causes of stress

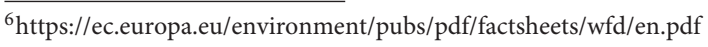


and define the most beneficial blend, geographic placement and timing of management actions (Omerod et al., 2010; Craig et al., 2017). This approach has worked reasonably well for the urban stream "syndrome" (Sheldon et al., 2012; Booth et al., 2016). Other multiple-stressor syndromes that threaten freshwater ecosystems include irrigated agriculture, forestry, mining, energy production, transport systems and the recreation and tourism sectors. Climate change, itself a complex mix of stressors, already compounds multiple stressor syndromes (Sabater et al., 2018), by altering river flow and flooding regimes, while rising temperatures are driving higher evaporation rates, water scarcity, and aquatic habitat loss. Shifting climatic regimes intensify the urgency of multiple stressor research and adaptive management solutions.

In multiple-stressor contexts, Tickner et al. (2020) recommend the assembly of "strategic portfolios of measures" rather than relying on interventions that address individual stressors, although these will always be necessary in particular contexts. Methods for mapping individual and cumulative stressors are well-developed (e.g., Vörösmarty et al., 2010), and analytical tools for prioritizing ecological restoration among sites in multi-stressor landscapes are emerging (Hermoso et al., 2015; Neeson et al., 2016). Strategic portfolios of restoration measures require development of cause-and-effect relationships to understand and predict the responses of species and communities to individual and multiple-stressor configurations. Maasri et al. (2021) recommend assessment of restoration outcomes using large-scale replication of before-after-controlimpact (BACI) designs, and long-term post-monitoring phases. Relatively few restoration projects meet these stringent design and monitoring requirements (Palmer et al., 2005; Geist and Hawkins, 2016). Meta-analyses of results from post-monitoring can help to identify restoration failures (often under-reported, Geist, 2011) as well as successes, extract learnings and guide adaptation toward more effective strategies.

In many situations with a long history of anthropogenic stress it is important to be realistic about the potential for restoration of near-natural ecological systems (Geist and Hawkins, 2016). Rehabilitation or remediation to recover and sustain selected ecosystem values and species may be the only feasible approach, especially where novel ecosystems with well-established alien species have replaced natural system structures, biodiversity and processes, as in many impounded rivers and degraded floodplain wetlands (Acreman et al., 2014; Poff et al., 2017). These novel circumstances require careful development of explicit and realistic targets for the recovery of the system at project onset (Geist, 2011, 2015; Geist and Hawkins, 2016). A framing termed Strategic Adaptive Management (SAM) offers a structured step-wise process from development of a shared vision and hierarchy of objectives linked to management actions, monitoring, evaluation and publication of outcomes (Kingsford et al., 2021). It amply meets the criteria for measuring restoration and management success from an ecological perspective (Palmer et al., 2005) and provides a powerful model of effective stakeholder collaboration. Broad stakeholder engagement throughout project design, implementation and monitoring strengthens comprehension of the multiple challenges of ecosystem restoration, and encourages appreciation of what can be achieved and is worthy of investment.

Freshwater ecosystem restoration, rewilding, rehabilitation and remediation are technically feasible with existing and emerging technologies, collaborative human commitment and adequate resourcing. The IUCN ecosystem typology provides a template for identification of risks and restoration priorities at global scale. As an example, severe threats to freshwater biodiversity in the Amazon Basin (overexploitation, deforestation, extensive hydroelectric dam development and climate change) demand a portfolio of recovery actions (Duponchelle et al., 2021) and spatially explicit prioritization of future hydropower developments to minimize loss of aquatic connectivity and biodiversity (Winemiller et al., 2016).

\section{PROTECED AREA DESIGN AND MANAGEMENT}

Ecosystem restoration is challenging, expensive and may require decades of sustained effort to maintain the desired outcomes. Prevention of biodiversity loss is a far better option than struggling for cures. Perfectly located, designed and managed freshwater protected areas (PAs) represent the pinnacle of global conservation policy. Many categories of area-based protected ecosystems (IUCN I-VI PAs, Ramsar list of Wetlands of International Importance, private protected areas, landholder covenants, indigenous stewardship) play significant roles in freshwater biodiversity conservation. In 2010, the Convention on Biological Diversity (CBD) included an area target of $17 \%$ protection for inland waters. However, $70 \%$ of river reaches (by length) have no protected areas in their upstream catchments, and only $11.1 \%$ (by length) achieve full integrated protection (Abell et al., 2017). Seasonal inland wetlands represent $\sim 6 \%$ of the world's land surface, yet around $89 \%$ are unprotected by IUCN PAs and Ramsar sites (Reis et al., 2017).

Urgent calls for increased protection of freshwater ecosystems and biodiversity include free-flowing rivers (Perry et al., 2021), river-wetland mosaics (Reis et al., 2017), springs (Cantonati et al., 2020) and other groundwater-dependent ecosystems, as well as integrated terrestrial-freshwater-estuary/marine protection coordinated across spatial scales, jurisdictions and sectors (Abell et al., 2017; Leal et al., 2020; Buxton et al., 2021). Systematic conservation planning offers data-driven methods for prioritizing restoration and protected area strategies (Abell et al., 2017; Linke et al., 2019). Applications of these approaches have addressed vital issues for freshwater conservation planning (source catchment condition, dimensions of river connectivity, integrated river, wetland and aquifer protection, threatening processes, species distribution shifts under climate change, and trade-offs between freshwater biodiversity conservation and human water requirements). Other tools that can aid similar spatial analysis, provide insights into trade-offs, and inform strategic multi-objective decision-making include pareto-optimal assessments (Hurford and Harou, 2014), Strategic Environmental Assessment (Lazarus et al., 2018) and system-scale infrastructure planning 
(Winemiller et al., 2016; Opperman et al., 2019).

Significant improvements in the placement, spatial configuration and connectivity of protected areas are feasible using these techniques.

Recent studies have sought to evaluate the benefits of freshwater protected areas for conservation of freshwater biodiversity. A systematic review found that only $51 \%$ of 75 case studies demonstrated beneficial outcomes relative to comparable unprotected areas (Acreman et al., 2020). Activities within and external to protected areas were held responsible, including landscape modifications, riparian loss, alterations to hydrological regimes, loss of floodplain connectivity, habitat alterations, chemical contamination, fishing, harvesting (e.g., turtle eggs) and the presence of non-native species. Over-exploited and degraded protected areas add to the burden of ecosystem restoration and recovery facing many societies. Ecological principles and guidelines for improved use, management and monitoring of freshwater protected areas and their surrounding landscapes warrant far wider appreciation and application (Finlayson, 2018; Acreman et al., 2020).

Strengthening the conservation benefits of freshwater protected areas requires engagement and collaboration among scientists, management agencies and the people who visit, know and use these areas. Increased public engagement, citizen science and participatory monitoring of trends in condition or species abundance by committed stakeholders can raise the profile of freshwater biodiversity and help to change behaviors that might otherwise lead to ecosystem damage. Positive socio-economic outcomes as well as biodiversity conservation are important, and more likely to occur when PAs adopt co-management regimes (e.g., fisheries), empower local people, reduce economic inequalities, and maintain cultural and livelihood benefits (Oldekop et al., 2016).

\section{SOCIO-ECOLOGICAL SCIENCE AND GOVERNANCE}

Freshwater ecosystems and their catchments are increasingly viewed as coupled human and natural systems, wherein setting objectives and devising management solutions, require engagement and collaboration among engineers and hydrologists, ecologists, social scientists and citizens (Bunn, 2016). This has been advocated and implemented in the field of environmental water management for decades (Poff et al., 2003, 2017) and is a strong element of The Brisbane Declaration and Global Action Agenda on Environmental Flows (Arthington et al., 2018; Anderson et al., 2019). Ecosystem-based Management (EBM), also referred to as the 'Ecosystem Approach', jointly considers societal and ecological goals and scenarios in an impressive modeling framework (Langhans et al., 2019). The EBM and similar framings (e.g., SAM) recognize the need for coupling of social and ecological systems, and engagement of all stakeholders. The concept of "stakeholders" has often meant token representation of indigenous, marginalized or poorly recognized societal groups. Yet increasingly, solving complex conflicts about water use and management, especially in times of scarcity and uncertainty, requires collaboration and enduring partnerships among all stakeholders with indigenous, societal and scientific knowledge, technical expertise, and credentials at all levels of governance.

Recent reviews consistently call for improved practices to enhance communication, understanding and respect for different "ways of knowing," and methods for blending of stakeholder knowledge (especially indigenous knowledge) with conventional science (Anderson et al., 2019; Buxton et al., 2021; Maasri et al., 2021; Perry et al., 2021). Others call for evidence-based and targeted guidance to facilitate working with the complex dynamic interactions of ecological and societal systems (Harper et al., 2021). The framing termed Coupled Human and Natural Systems (CHANS) is especially relevant. It proposes strategic integration of patterns and processes that connect human and natural systems, as well as within-scale and cross-scale interactions and feedbacks between human and natural components of such systems (Liu et al., 2021). Interesting applications to freshwater systems include evaluation of water availability, use, quality, management and governance in Canadian agricultural watersheds (Liu et al., 2019) and fisheries management (Lynch and Liu, 2014).

CHANS, SAM and EBM embrace important principles of socio-ecological collaboration and governance, including building trust, maintaining respectful interactions, upholding rights, embracing mutual understanding, and development of enduring partnerships. These integrated socio-ecological frameworks and partnership models offer fundamental tools to guide understanding and management of increasingly degraded Anthropocene ecosystems, in which societal and ecological processes are deeply entwined and interact. Socioecological systems in turn require participatory management and governance regimes that can foster biodiversity conservation alongside societal benefits and social justice. For example, a "Just Aquatic Governance" framework has been proposed for the Amazon Basin, based on three pillars of social justice: recognitional, procedural and distributional (Lopes et al., 2021). The need for inclusive socio-ecological freshwater science and governance is particularly acute in the biodiverse, multicultural Amazon Basin (Castello, 2021).

\section{CONCLUDING COMMENTS}

The Post-2020 Global Biodiversity Framework is visionary and compelling, and especially relevant to the recovery of freshwater biodiversity-the most overlooked and urgent conservation challenge of the next decade. The IUCN has distinguished 28 global freshwater ecosystem types, a powerful framing for activities to promote the recovery and conservation of freshwater biodiversity. This challenge paper supports the freshwater Emergency Recovery Plan by promoting a broader package of strategic activities that too often operate in silos, with patchy coverage of the world's freshwater ecosystem types and biogeographic diversity and cultural heritage.. This portfolio urges integration of biodiversity inventory and basic ecosystem science, stressor assessment and mapping with 
systematic restoration and protected area management in a strategic global freshwater conservation strategy, with links to terrestrial and estuarine/marine realms as required. An overarching and integrative theme is the coupling of ecological and human systems, and the importance of collaboration among all stakeholders with indigenous, societal and scientific knowledge, technical expertise, and experience with governance models and policy development. There is an urgent need to build shared knowledge, trust, mutual understanding and

\section{REFERENCES}

Abell, R., Lehner, B., Thieme, M., and Linke, S. (2017). Looking beyond the fence line: assessing protection gaps for the world's rivers. Conserv. Lett. 10, 384-394. doi: $10.1111 /$ conl.12312

Acreman, M., Arthington, A. H., Colloff, M. J., Couch, C., Crossman, N. D., Dyer, F., et al. (2014). Environmental flows for natural, hybrid, and novel riverine ecosystems in a changing world. Frontiers Ecol. Env. 12, 466-473. doi: $10.1890 / 130134$

Acreman, M., Hughes, K. A., Arthington, A. H., Tickner, D., and Dueñas, M.-A. (2020). Protected areas and freshwater biodiversity: a novel systematic review distils eight lessons for effective conservation. Conserv. Lett. 13, e12684-e12020. doi: $10.1111 /$ conl. 12684

Anderson, E. P., Jackson, S., Tharme, R. E., Douglas, M., Flotemersch, J. E., Zwarteveen, M., et al. (2019). Understanding rivers and their social relations: a critical step to advance environmental water management. WIREs Water. 6:e1381. doi: 10.1002/wat2.1381

Arthington, A. H., Bhaduri, A., Bunn, S. E., Jackson, S., Tharme, R. E., Tickner, D., et al. (2018). The brisbane declaration and global action agenda on environmental flows (2018). Front. Environ. Sci. 6:45. doi: 10.3389/fenvs.2018.00045

Booth, D. B., Roy, A. H., Smith, B., and Capps, K. A. (2016). Global perspectives on the urban stream syndrome. Freshw. Sci. 35, 412-420. doi: 10.1086/684940

Bunn, S. E. (2016). Grand Challenge for the Future of Freshwater Ecosystems. Front. Environ. Sci. 4:21. doi: 10.3389/fenvs.2016.00021

Buxton, R. T., Bennett, J. R., Reid,. A. J., Shulman, C., Cooke, S. J., Francis, C. M., et al. (2021). Key information needs to move from knowledge to action for biodiversity conservation in Canada. Biol. Conserv. 256:108983. doi: 10.1016/j.biocon.2021.108983

Cantonati, M., Fensham, R. J., Stevens, L. E., Gerecke, R., Glazier, D. S., Goldscheider, N., et al. (2020). Urgent plea for global protection of springs. Conserv. Biol. 35, 378-382. doi: 10.1111/cobi.13576

Castello, L. (2021). Science for conserving Amazon freshwater ecosystems. Aquatic Conserv. (in press)

Craig, L. S., Olden, J. D., Arthington, A. H., Entrekin, S., Hawkins, C. P., Kelly, J. J., et al. (2017). Meeting the challenge of interacting threats in freshwater ecosystems: a call to scientists and managers. Elementa 5:72. doi: 10.1525/elementa.256

Darwall, W., Bremerich, V., De Wever, A., Dell, A. I., Freyhof, J., Gessner, M. O., et al. (2018). The Alliance for Freshwater Life: A global call to unite efforts for freshwater biodiversity science and conservation. Aquatic Conserv. 28, 1015-1022. doi: 10.1002/aqc.2958

Datry, T., Boulton, A. J., Bonada, N., Fritz, K., Leigh, C., Sauquet, E., et al. (2018). Flow intermittence and ecosystem services in rivers of the Anthropocene. J. Appl. Ecol. 55, 353-364. doi: 10.1111/1365-2664. 12941

Dudgeon, D., Arthington, A. H., Gessner, M. O., Kawabata, Z. I., Knowler, D. J., Leveque, C., et al. (2006). Freshwater biodiversity: importance, threats, status and conservation challenges. Biol. Rev. 81, 163-182. doi: $10.1017 /$ S1464793105006950

Duponchelle, F., Isaac, V. J., Doria, C., Van Damme, P. A., Herrera,-R., G. A., et al. (2021). Conservation of migratory fishes in the Amazon basin. Aquatic Conserv. doi: $10.1002 /$ aqc. 3550 enduring respectful partnerships in coupled human-ecological systems if we want a world of people "living in harmony with nature."

\section{AUTHOR CONTRIBUTIONS}

The author confirms being the sole contributor of this work and has approved it for publication.
Finlayson, C.M., Arthington, A.H., and Pittock, J. (Eds.) (2018). Freshwater Ecosystems in Protected Areas: Conservation and Management. Earthscan Studies in Water Resource Management. London: Taylor and Francis Group; Routledge. doi: 10.4324/9781315226385

Flitcroft, R., Cooperman, M. S., Harrison, I. J., Juffe-Bignoli, D., and Boon, P. J. (2019). Theory and practice to conserve freshwater biodiversity in the Anthropocene. Aquatic Conserv. 29, 1013-1021. doi: 10.1002/aqc.3187

Geist, J. (2011). Integrative freshwater ecology and biodiversity conservation. Ecol. Indic. 11, 1507-1516. doi: 10.1016/j.ecolind.2011.04.002

Geist, J. (2015). Seven steps towards improving freshwater conservation. Aquatic Conserv. 25, 447- 453. doi: 10.1002/aqc.2576

Geist, J., and Hawkins, S. J. (2016). Habitat recovery and restoration in aquatic ecosystems: current progress and future challenges. Aquatic Conserv. 26, 942-962 doi: $10.1002 /$ aqc. 2702

Grill, G., Lehner, B., Thieme, M., Geenen, B., Tickner, D., Antonelli, F., et al. (2019). Mapping the world's free-flowing rivers. Nature 569, 215-221. doi: 10.1038/s41586-019-1111-9

Harper, M., Mejbel, H. S., Longert, D., Abell, R., Baird, T. D., Bennett, J. R., et al. (2021). Twenty-five essential research questions to enhance the protection and restoration of freshwater biodiversity. Aquatic Conserv. (in press).

Hermoso, V., Pantus, F., Olley, J., Linke, S., Mugodo, J., and Lea, P. (2015). Prioritising catchment rehabilitation for multi objective management: an application from SE-Queensland, Australia. Ecol. Model. 316, 168-175. doi: 10.1016/j.ecolmodel.2015.08.017

Horne, A. C., Webb, J. A., Stewardson, M. J., Richter, B. D., and Acreman, M. (Eds). (2017). Water for the Environment: From Policy and Science to Implementation and Management. Cambridge, MA: Elsevier.

Hurford, A. P., and Harou, J. J. (2014). Balancing ecosystem services with energy and food security - assessing trade-offs from reservoir operation and irrigation investments in Kenya's Tana Basin. Hydrol. Earth Syst. Sci. 18, 3259-3277. doi: 10.5194/hess-18-3259-2014

Keith, D.A., Ferrer-Paris, J.R., Nicholson, E., and Kingsford, R.T. (Editors) (2021). IUCN Global Ecosystem Typology 2.0: descriptive profiles for biomes and ecosystem functional groups. IUCN, Gland, Switzerland. Available online at: https://portals.iucn.org/library/node/49250

Kingsford, R. T., McLoughlin, C. A., Brandle, R., Bino, G., Cockayne, B., Schmarr, D., et al. (2021). Adaptive management of Malkumba-Coongie Lakes ramsar site in Arid Australia-a free flowing river and Wetland System. Sustainability 13:3043. doi: 10.3390/su13063043

Langhans, S. D., Domisch, S., Balbi, S., Delacámara, G., Hermoso, V., Kuemmerlene, M., et al. (2019). Combining eight research areas to foster the uptake of ecosystem-based management in fresh waters. Aquatic Conserv. 29, 1161- 1173. doi: 10.1002/aqc.3012

Lazarus, K. M., Corbett, M., Cardinale, P., Lin, N. S., Noeske, T., Kumar, V., et al. (2018). Strategic Environmental Assessment of the Myanmar Hydropower Sector. Washington, DC: International Finance Corporation. Available online at: www. elibrary.worldbank.org

Leal, C. G., Lennox, G. D., Ferraz, S. F. B., Ferreira, J., Gardner, T. A., et al. (2020). Integrated terrestrial-freshwater planning doubles conservation of tropical aquatic species. Science 370, 117-121. doi: 10.1126/science.aba7580

Linke, S., Hermoso, V., and Januchowski-Hartley, S. (2019). Toward process-based conservation prioritizations for freshwater ecosystems. Aquatic Conserv. 29, 1149- 1160. doi: 10.1002/aqc.3162 
Liu, J., Baulch, H. M., Macrae, M. L., Wilson, H. F., Elliott, J. A., Bergstrom, L., et al. (2019). Agricultural water quality in cold climates: processes, drivers, management options, and research needs. J. Env. Quality 48, 792-802. doi: $10.2134 /$ jeq2019.05.0220

Liu, J., Dietz, T., Carpenter, S. R., Taylor, W. W., Alberti, M., Deadman, P., et al. (2021). Coupled human and natural systems: the evolution and applications of an integrated framework. Ambio. doi: 10.1007/s13280-020-01488-5

Lopes, P. F. M., de Freitas, C. T., Hallwass, G., Silvano, R. A. M., Begossi,A., and Campos-Silva, J.V. (2021). Just aquatic governance: the amazon basin as fertile ground for aligning participatory conservation with social justice. Aquatic Conserv. doi: 10.1002/aqc.3586

Lynch, A., and Liu, J. (2014). "Fisheries as coupled human and natural systems," in Future of Fisheries: Perspectives for Emerging Professionals, ed. W.W. Taylor, A. Lynch, and N. Leonard, (Washington, DC: American Fisheries Society Press).

Lynch, A. J., Cooke, S. J., Deines, A. M., Bower, S. D., and Bunnell, D. B., Cowx, I.G., et al. (2016). The social, economic, and environmental importance of inland fish and fisheries. Environ. Rev. 24, 115-121. doi: 10.1139/er-2015-0064

Maasri, A., Jähnig, S. C., Adamescu, M. C., Adrian, R., Baigun, C., Baird, D., et al. (2021). A Global Agenda for Advancing Freshwater Biodiversity Research. Authorea. doi: 10.22541/au.161640764.49902060/v1

Neeson, T. M., Smith, S. D. P., Allan, J. D., and McIntyre, P. B. (2016). Prioritizing ecological restoration among sites in multi-stressor landscapes. Ecol. Appl. 26, 1785-1796. doi: 10.1890/15-0948.1

Oldekop, J. A., Holmes, G., Harris, W. E., and Evans, K. L. (2016). A global assessment of the social and conservation outcomes of protected areas. Cons. Biol. 30, 133-141. doi: 10.1111/cobi.12568

Omerod, S. J., Dobson, M., Hildrew, A. G., and Townsend, C. R. (2010). Multiple stressors in freshwater ecosystems. Freshw. Biol. 55 (Suppl. 1); 1-4. doi: 10.1111/j.1365-2427.2009.02395.x

Opperman, J. J., Kendy, E., and Barrios, E. (2019). Securing environmental flows through system reoperation and management: lessons from case studies of implementation. Front. Environ. Sci. 7:104. doi: 10.3389/fenvs.2019.00104

Palmer, M., Bernhardt, E., Allan, J. D., Lake, P. S., Alexander, G., Brooks, S., et al. (2005). Standards for ecologically successful river restoration. J. App. Ecol. 42, 208-217. doi: 10.1111/j.1365-2664.2005.01004.x

Perry, D., Harrison, I., Fernandes, S., Burnham, S., and Nichols, A. (2021). Global analysis of durable policies for free-flowing river protections. Sustainability 13:2347. doi: 10.3390/su13042347

Poff, N. L., Allan, J. D., Palmer, M. A., Hart, D. D., Richter, B. D., Arthington, A. H., et al. (2003). River flows and water wars: emerging science for environmental decision making. Front. Ecol. Env. 1, 298-306. doi: 10.1890/1540-9295(2003)001[0298:RFAWWE]2.0.CO;2
Poff, N. L., Tharme, R. E., and Arthington, A. H. (2017). "Evolution of environmental flows assessment science, principles, and methodologies," in Water for the Environment, eds A. C. Horne, J. A. Webb, M. J. Stewardson, B. Richter, and M. Acreman (London: Academic Press), 203-236. doi: 10.1016/B978-0-12-803907-6.00011-5

Reid, A. J., Carlson, A. K., Creed, I. F., Eliason, E. J., Gell, P. A., Johnson, P. T., et al. (2019). Emerging threats and persistent conservation challenges for freshwater biodiversity. Biol. Rev. 94, 849-873. doi: 10.1111/brv.12480

Reis, V., Hermoso, V., Hamilton, S. K., Ward, D., Fluet-Chouinard, E., Lehner, B., et al. (2017). A global assessment of inland wetland conservation status. Bioscience 67, 523- 533. doi: 10.1093/biosci/bix045

Sabater, S., Elosegi, A., and Ludwig, R. (2018). Multiple Stressors in River Ecosystems: Status, Impacts and Prospects for the Future. Amsterdam: Elsevier.

Sheldon, F., Peterson, E. E., Boone, E. L., Sippel, S., Bunn, S. E., and Harch, B. D. (2012). Identifying the spatial scale of land-use that most strongly influences overall river ecosystem health score. Ecol. Appl. 22, 2188-2203. doi: 10.1890/11-1792.1

Tickner, D., Opperman, J. O., Abell, R., Acreman, A., Arthington, A. H., Bunn, S. E., et al. (2020). Bending the curve of global freshwater biodiversity loss: an emergency recovery plan. BioScience 70, 330-342, doi: 10.1093/biosci/biaa002

van Rees, C. B., Waylen, K. A., Schmidt-Kloiber, A., Thackeray, S. J., Kalinkat, G., Martens, K., et al. (2020). Safeguarding freshwater life beyond 2020: recommendations for the new global biodiversity framework from the European experience. Conserv. Lett. 4:e12771. doi: 10.20944/preprints202001.0212.v1

Vörösmarty, C. J., McIntyre, P. B., Gessner, M. O., Dudgeon, D., Prusevich, A., Green, P. A., et al. (2010). Global threats to human water security and river biodiversity. Nature 467, 555-561. doi: 10.1038/nature09440

Winemiller, K. O., McIntyre,P. B., Castello, L., Fluet-Chouinard, E., and Giarrizzo, T., Nam, S. et al. (2016). Balancing hydropower and biodiversity in the Amazon, Congo, and Mekong. Science 351, 128-129. doi: 10.1126/science.aac7082

Conflict of Interest: The author declares that the research was conducted in the absence of any commercial or financial relationships that could be construed as a potential conflict of interest.

Copyright (c) 2021 Arthington. This is an open-access article distributed under the terms of the Creative Commons Attribution License (CC BY). The use, distribution or reproduction in other forums is permitted, provided the original author $(s)$ and the copyright owner(s) are credited and that the original publication in this journal is cited, in accordance with accepted academic practice. No use, distribution or reproduction is permitted which does not comply with these terms. 